\title{
Do municipal amalgamations affect interregional migration?
}

\author{
Vífill Karlsson, Consultant, West-Iceland Regional Development and \\ Associate Professor, University of Akureyri \\ Grétar Thór Eythórsson, Professor, University of Akureyri
}

\begin{abstract}
This paper examines the change of interregional migration following municipal amalgamations. Interregional migrations are mostly triggered by differentials in household utilities, local economic conditions, amenities and the like. Thus, it is reasonable to believe that if an amalgamation of municipalities leads to a better service or lower local taxes in a community, it would attract new inhabitants and thus, increase the net-migration - as suggested by Tiebout (1956). A macro panel data set from Iceland was used that represents several essential variables of the housing market for 79 municipalities in Iceland during the period from 1993 to 2006. The results returned mixed effects on net migration. The amalgamations seem to have had both negative and positive effects on net-migration due to the differences in the number of municipalities in each merger and the similarities in the population sizes of the previous municipalities that joined each merger.
\end{abstract}

Keywords: Municipal amalgamations; interregional migration; territorial reforms; municipal structure; Icelandic municipalities.

\section{Introduction}

Does interregional migration change follow municipal amalgamations? As in several other European countries, Iceland has had repeated municipal amalgamations, especially since the mid 1990's (Steiner, Kaiser, \& Eythórsson 2016). The general discussion regarding municipal amalgamations suggests that due to the presence of scale economies, they lead to a lower average cost for the municipalities involved. This has, however, not

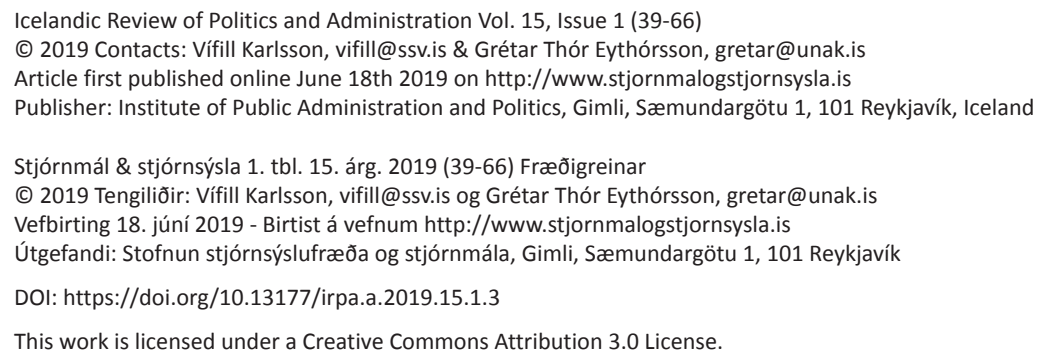


been easily confirmed by empirical research (Fox \& Gurley 2006, 35), in part since it leaves out the possibility that the economic return of the amalgamation will be spent on improved services. It is, however, much harder in quantitative research to estimate service quality than lower average cost. It is even possible that the benefit following amalgamation is spent on paying debts that would lead to reduced expenditure on interest payments and generate resources, either to increase service level or lower taxes. So, either way, if municipal amalgamation is successful, it should be detected by the citizens and informed people in other municipalities and regions. Therefore, it would affect net-migration, as suggested by Tiebout (1956). Using an alternative method, this paper contributes to detecting the change in local government average cost and service level following an amalgamation.

The standard economic theory and model and the simplest one for interregional migration suggests that regional (real) wage differentials motivate potential migrants to move (Hicks 1932; Hunt 1993; McCann 2001). Tiebout's (1956) theory is more complex in that it provides additional factors to that context.

According to Tiebout (1956), regions attract new migrants if local service improves or local taxes are reduced. Either of these can occur if a municipal amalgamation is successful and returns lower operational costs per inhabitant. Therefore, a municipality will experience improved net migration following an amalgamation if it generates a lower cost per inhabitant, resulting in either better services or lower taxes.

Many economists have contributed to Tiebout's theory. Graves (1979) continued with the relationship between climate and net migration when he disaggregated the sample by age and race. Quality of life was the topic of Roback's (1982) paper, which attempted to determine the various impacts of amenities on local economic factors. Blomquist, Berger and Hoehn (1988) pointed out that interregional amenity differences involve more than public services and include quality of life, such as weather conditions, crime and pollution, among other factors. Their analysis revealed that quality of life does matter to migration, as earlier research concluded, and that "compensation for locationspecific, non-traded amenities takes place in both the labour and the housing market" (Blomquist et al. 1988, 105).

The contribution of this article is a new approach to detecting the total net-impact of amalgamation of municipalities. If successful, an amalgamation must lead to migration movements if so perceived by the citizens of affected municipalities - or, in other words, migrants will vote with their feet. So, by estimating the migration movement following municipal amalgamations, the net impact is revealed. If Tiebout (1956) was right, this is the only way to detect whether there is any net return of an amalgamation of municipalities. All prior approaches have focused on the estimation of either the impact of the amalgamations on the operational costs of municipalities, lower taxes, or improved services, with a vast majority of them concerning themselves with operational costs. In such cases, it is hard to capture the true financial impact of an amalgamation if the operational costs have not been lowered, since potential savings could have been spent on better services, lower local taxation or reduced local public service fees (such 
as for kindergardens, public swimming pools, cold water, removal of waste disposal and sewage).

The analysis conducted in this article relied on a new migration model and a large panel data set from Iceland (Karlsson 2013). The data for the amalgamation was added to the database from that research and the analysis repeated accordingly. So, the present work builds on the original analysis (Karlsson 2013) in detecting possible explanations for the relatively large interregional migration that has been occurring in Iceland, especially for the past four decades or so.

The amalgamation was tested in two separate estimations. First the relationship between interregional net migration of all amalgamations was estimated (Models 3 and 4). Secondly, the relationship between interregional net migration was assessed against several types of amalgamations, traced back to the number of municipalities that merged into one new municipality whether they were similar in the number of inhabitants or not (Models 1 and 2). There was reason to believe that the net benefit of an amalgamation could be affected by its specific characteristics regarding the number of joined municipalities and their size on the following grounds. The number of joined municipalities can be relevant, because if there are any scale economies (Rosen 2008; Burridge 2008), the marginal impact of an amalgamation will be dependent on the size and the number of joined municipalities. Thus, the amalgamations of three small municipalities can return a greater net benefit than the merger of a large municipality and a small one. The net benefit of an amalgamation can also be lowered by the transaction cost generated in the amalgamation process. It might be higher when the number of participants increases and can move the solution from its social maximum as in the case of the Coase theorem. The similarity of municipalities can also affect the potential benefit of an amalgamation through the transaction cost.

The organisation of this article is as follows. Section 2 is derived from the empirical model and Section 3 from the literature review. Section 4 addresses the empirical model that will be implemented, and Section 5 describes data construction and handling. Section 6 contains the analysis and the results. Finally, a summary and concluding remarks are presented in Section 7 and Section 8 presents the conclusion.

\section{The municipal level in Iceland}

Iceland has a two-tier system of administration, the state level and the local level. A regional level with elected officials does not exist and almost never has. Local selfgovernment is protected by Article 78 of the Constitution of the Republic of Iceland (1999) The interpretation is that local authorities may do what they wish or assign tasks to another body, as long as it is not prohibited by state law (Valsson 2014; Hlynsdóttir 2015). A main characteristic of the Icelandic local government system is the proportionally large number of small, sparsely-populated municipalities - something that is evident in comparison with other European nations (Baldersheim \& Rose 2010, 3; Karlsson \& Jóhannesson 2014, 18). The very smallest ones are, in many cases, agricultural communities without even any villages and a population close to 50 inhabitants. At the same 
time, the capital of Reykjavík has a population of over 120,000. But the small units are proportionally numerous. Even though the mean size is about 4,500 , the median size is only just below 900 .

The municipal geography of Iceland can be described in terms of three characteristics, where the high rate of urbanization and concentration of population in the capital area is the most striking aspect:

1. The area surrounding the capital, Reykjavík, constitutes by far the most populated area. The Reykjavík municipality has over 126,000 inhabitants, followed by its close neighbours, Kópavogur (36,000) and Hafnarfjörður (29,000). These municipalities contain close to two-thirds of the total population of Iceland (almost 350,000) and are thus by far the largest municipalities in terms of population. Only Akureyri in the north comes anywhere close (19,000). At the moment, Garðabær $(16,000)$ in the capital area and Reykjanesbær $(18,000)$ in the south-west are coming closer to Akureyri in population size.

2. Counting all the municipalities within commuting distance to and from Reykjavík (that is, a radius of some $60-70 \mathrm{~km}$ ), one finds almost 80 percent of the island's total population. This includes such municipalities as Reykjanesbær (18,000), Akranes (7,000) and Árborg (9,000).

3. Apart from Akureyri (18,300), at a distance of $400 \mathrm{~km}$ from Reykjavík, only a few municipalities outside the greater capital region have more than 3,000 inhabitants. These are Ísafjarðarbær in the northwest (3,700), Skagafjörður in the north (4,000), Fjarðabyggð (4,800), Fljótsdalshérað $(3,500)$ in the east and Vestmannaeyjar off the south coast $(4,300)$.

Local government expenditures constitute $30.9 \%$ of the total public spending ${ }^{1}-$ which is low in comparison with the other Nordic countries, where the local level expenditure is between $60 \%$ and $70 \%$. Municipal revenues are mainly through income taxes $(58 \%)$, and the remainder is through real estate taxes $(12 \%)$, contributions from the Equalisation Fund $(12 \%)$ and other income $(18 \%)^{2}$.

A broad range of services of the following categories are provided by local government. ${ }^{3}$ Obligatory services are noted as such; all others listed are provided at the discretion of each specific municipality.

1. Education

- Primary schools (obligatory)

- Kindergartens

- Music schools

2. Social services - (obligatory)

- Social and financial counselling contribution

- Provision of social home care

- Unemployment and employment services 
- Affairs of children and youth

- Handicapped affairs

- Elderly care (in cooperation with the state)

- Homeless, alcoholics and drug addicts

3. Health care centres - (obligatory)

- Health surveillance (in cooperation with the state)

4. Culture

- Cultural museums

- Community centres

- Arranging festivals which form part of the local culture

- Public libraries (obligatory)

5. Sports and youth welfare

- Playgrounds

- Youth centres

- Central baths

- Sports centres

- Sports arenas

6. Fire department and public disaster protection - (obligatory)

7. Hygiene - (obligatory)

- Health control

8. Planning and construction - (obligatory)

9. Traffic and transportation - (obligatory)

- Construction and maintenance of municipal roads

10. Environmental affairs

- Public parks, cleaning and cultivation of road surroundings and managing of public decorations

11. Industrial affairs

- Municipalities can choose to assist selected branches of industry if found to be necessary, such as agriculture and tourism

In addition to belonging to The Association of Local Authorities in Iceland (Samband Sveitarfélaga), the municipalities operate eight regional associations. These associations pursue the joint interests of the local authorities in each region. In some instances, the regional associations have also been entrusted with special operational tasks of the local authorities, such as refuse disposal and the operation of school offices. Inter-municipal cooperation is widespread. A total of 197 formal cooperation entities or arrangements exist as a whole throughout the country, and the average municipality is involved in 13.5 cooperation arrangements. This, however, varies from 6 to 23. By far, the most frequent 
areas of cooperation are primary schools and social services (Jóhannesson et al. 2016; Eythórsson 2017).

\subsection{The amalgamation development}

The number of municipalities increased slowly from the beginning until the middle of the twentieth century when it reached its peak at 229. After that, a slow decrease began. The main reason for the increasing number of municipalities until the 1950s was the industrialization of fishing, causing people to move from the countryside to the coast in order to work where there were better hopes of earning a decent income. This meant that new communities in the form of fishing villages sprang up and then became established as municipalities. After this period, the decrease in the number of municipalities is mainly explained by two forces - the total depopulation of a number of rural municipalities and some amalgamations. The amalgamations were both a response and a means to defeat the rural depopulation. The changes since 1990 have been more or less facilitated by two referenda on municipal amalgamations - one in 1993 and the second in 2005 and their implications (Eythórsson 2009). Since 1993, the number of municipalities has fallen from 196 to 72, the current number. This is a reduction by 63\%, which is unquestionably among the largest reductions in Europe (Steiner, Kaiser, \& Eythórsson 2016). Nevertheless, the proportional number of small (and often peripheral) municipalities is high, so the question of reforming the municipal sector is still current in the debate on public sector reforms.

Two general and extensive reforms in the transfer of functions from the state to the local level have been implemented in Iceland, primary schools in 1996 and handicap services in 2011. Some smaller transfers or experiments have been conducted, such as a free-commune experiment in 1994 where a number of municipalities made contracts with the state for a few years to take over certain functions. Some of these are no longer valid, but others have turned out to be more permanent.

\subsection{Attitudes to territorial and functional reforms}

Among politicians at both the local and the state level, there were, after the 2005 referendum, signs of changing attitudes as to which means should be used to reinforce the municipal level in Iceland. Two surveys among all the local politicians in the country, in 2006 and 2011, show this (Figure 1). In 2006, 76\% were positive or firmly positive about taking over more functions, and 70\% felt the same way in 2011. Although interest had shrunk a little, it remained strong. Another question related to which functions people were interested in taking over from the state level. As the following figure shows, interest in elderly care was high on both occasions. 
Figure 1. Icelandic local politicians on the question: "If you think it is feasible that the municipalities should take over more functions from the state, which should those functions be?"

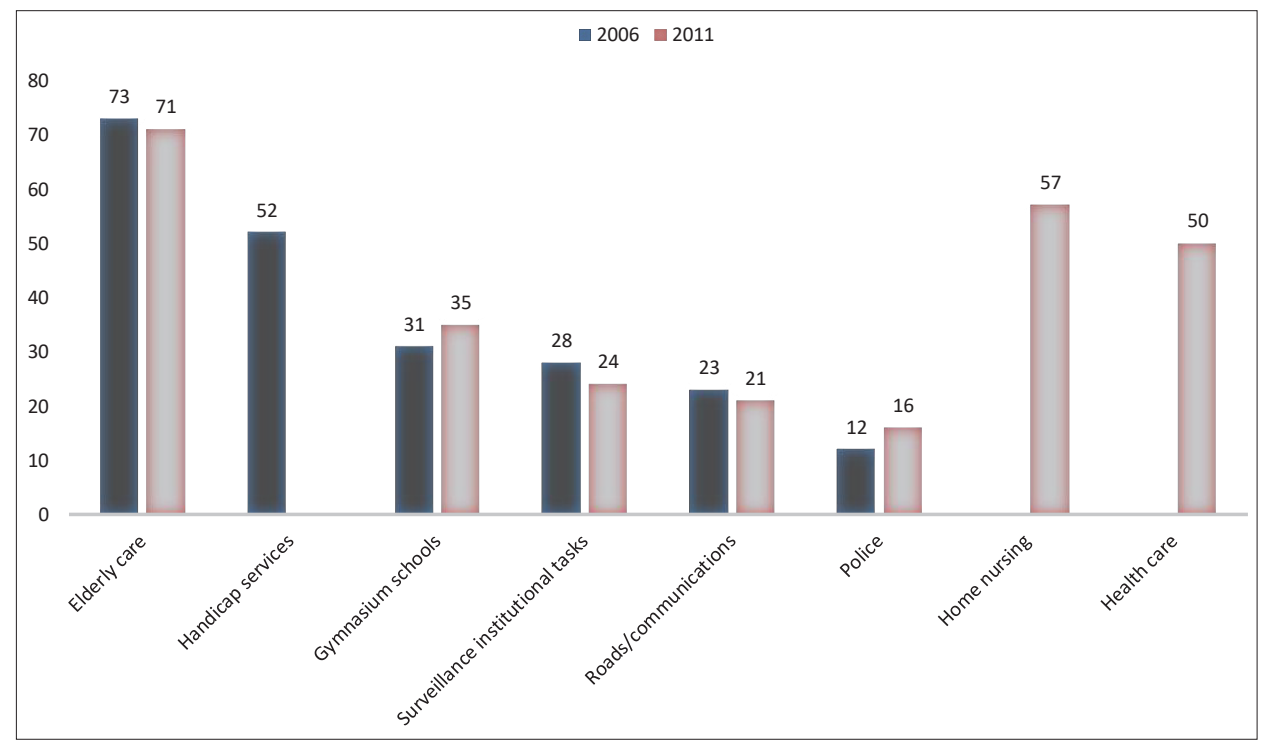

Source: Results from surveys in 2006 and $2011(\%){ }^{4}$

Interest in taking over home nursing and health care were high in 2011 and interest in gymnasium schools increased. These functions would require solutions in the form of inter-municipal cooperation in most cases due to the small size prevalent among Icelandic municipalities.

To sum up, local leaders in Iceland were found to be eager to strengthen the municipal level by taking over more functions from the state level. Two functions were decentralized in the last two decades, but there seems to be a strong interest in more decentralization, both among local leaders and parliament politicians. This has, for some time, been seen as best solved by inter-municipal cooperation arrangements. Currently, no further tasks have been transferred from the state to the local level since 2011. In 2016, a report from the University of Akureyri showed that inter-municipal cooperation arrangements were far more widespread than people seemed to have realized (Jóhannesson et al. 2016). Maybe this came as a shock, so that the only thing that now seems likely to happen in a reform direction is a slight awakening of interest in amalgamations. Two amalgamations took place in 2018 just before the local government elections.

\section{Literature review}

This section examines theories and empirical analysis related to the subject in order to address the empirical findings within the relevant research field and argue for the possible outcome of the study. 
Tiebout (1956) argued that the social benefit of local forms of administration, such as municipalities, could be traced back to the increased likelihood of state government meeting the different needs and wants of all the inhabitants of any community. Should there be many municipalities that provide different services (in terms of quantity, quality and variety), various inhabitants will improve their welfare by choosing their residence in a municipality of a more preferable service mix. One central government, the state, will never be as successful in providing suitable service for all members of the community, since any government has to treat all members equally. Accordingly, a municipality can lose part of its population when the service provided is changed or possibly attract new residents, ceteris paribus (even though the latter prospect was not mentioned in the initial version of the theory). Tiebout assumes scale economies in the operation of municipalities and the existence of their optimal size with respect to number of inhabitants, $m^{*}$, where the marginal revenue equals marginal cost:

\section{$\partial R / \partial m^{*}=\partial C / \partial m^{*}$}

The municipalities will adjust their services in order to attain $m^{*}$, and thus reach the optimal use of public resources. Tiebout also argued that the municipalities were better suited than the central government in identifying direct users of any service and charging them accordingly. Therefore, taxpayers are less likely to demand any service from the local government they are not willing to pay for and thus, the local administration becomes more efficient in providing the public service than the central government.

According to economic theory, economies of scale are present in the production of many goods and services. Scale economies have been detected in running services provided by Icelandic local and central governments. As an example, Burridge (2008) found evidence of scale economies in health care services, water supplies and telecommunications, and Rosen (2008) came to the same conclusion regarding fire departments and libraries. This also applies to teaching costs in primary and upper secondary schools. When teaching quality was taken into account, however, diseconomies of scale were detected. The findings of Duncombe and Yinger (2007) and Duncombe et al. (1995) supported this finding. Several studies have not been able to detect any scale economies or other proofs of lowered operational costs in relation to amalgamations of municipalities (Byrnes \& Dollery 2002; Dollery, Byrnes, \& Crase 2007; Dollery, Crase, \& Johnson 2006; Lüchinger \& Stutzer 2002). Thus, the literature on empirical studies returns mixed results for possible cost cuts in the wake of municipal amalgamations.

Dollery et al. (2006) suggested that smaller municipalities were not necessarily less cost-efficient than larger ones. Furthermore, they argued that municipal collaboration was more likely than amalgamation to generate operational cost efficiency. If that is true, the merging of Icelandic municipalities could show weak evidence for lower costs, since in their case, collaboration is very common. Research on compulsory and voluntary amalgamations of municipalities was conducted in Germany (Blesse \& Baskaran 2013). The study suggested that, in the short run, municipal overhead cost decreased following compulsory amalgamations, but less so in cases of voluntary mergers. Also, in the long 
run, compulsory amalgamations tended to decrease costs, whereas they increased in cases of voluntary mergers. The paper points out that municipalities that join voluntary mergers are generally fiscally weaker than those involved in compulsory amalgamations and have already made many attempts to improve their management by lowering their operational costs. This result suggests that amalgamations in Iceland may only have a limited effect on operational costs since these have almost all been voluntary.

A comparison of the development of the average cost of amalgamated and nonamalgamated municipalities in Finland during the period 1970-1981 was made by Moisio and Uusitalo (2013). They concluded that in all expense categories, average cost increased in the merged municipalities except for overhead costs. The reduction of overhead costs, however, was lower than the combined increase in other expense categories. These were all voluntary amalgamations. It is noteworthy, that the average operational costs of the merged municipalities remained higher than the non-merged costs, even ten years after the amalgamations.

A study based on municipal amalgamations in Denmark suggested that larger municipalities are no more cost efficient than smaller ones (Houlberg 2011). This was in 2007 when the number of municipalities decreased from 271 to 98. The analysis included only overhead costs. A more recent unpublished study (Blom-Hansen, Houlberg, \& Serritzlew 2011), however, of the same amalgamation process in Denmark detected a total cost reduction of approximately $8 \%$. These amalgamations were compulsory.

It could also be maintained, however, that a cost reduction following an amalgamation might be traced to a worsening service level. This does not have to be the case, however, since a study from Israel (Reingewertz 2012) detected a 9\% cost reduction and no notable change in service levels, following an amalgamation process that reduced the number of municipalities from 264 to 253 in 2003.

One Icelandic study, by Grétar Pór Eypórsson and Hjalti Jóhannesson (2002, 261) argued that the possible gains in terms of lower costs have been instantly spent on improved services. An Icelandic study (Karlsson \& Jónsson 2011-2012) indicated that, among all municipality affairs, overhead costs were most likely to be lowered following an amalgamation. A more recent study (Karlsson 2015) on Icelandic municipalities suggested a negligible change in operational costs following an amalgamation. The 2015 study differed from that of 2011-2012 in that the former was based on a data sample from the period 2004-2010 instead of one year, 2006, and panel data regression models were used instead of a cross-sectional, ordinary-least-squares (OLS) analysis.

According to Tyrefors Hinnerich (2009), relatively small municipalities are more likely than larger ones to launch investment projects to strengthen community infrastructure and run into higher debts prior to an amalgamation. If so, the total population of the new merged municipality will be paying for an investment that benefits mainly the population of only one of the previous municipalities. This result is in line with those of Jordahl and Liang (2010) and Blom-Hansen (2010). In such cases, it would be hard to detect any notable change in cost reduction or even better service following an amalgamation, if this had happened some years earlier without relevant information being 


\section{STJÓRNSÝSLA}

included in the analysis. It should be noted that amalgamations in Iceland have almost always included very sparsely populated municipalities.

Dur and Staal (2008) argued that a number of small municipalities become free riders because of the proximity to another municipality containing a populous city. In that case, the vast variety of the city's goods and services are more or less accessible to the inhabitants of the small municipality. Accordingly, the authorities of the small municipality are able to provide much more limited services than any other more remote municipality of that size without adversely affecting the welfare of its inhabitants. Moreover, residents of such a small municipality would most likely detect only a negligible change in the service level, following an amalgamation, since access was previously good.

When it comes to Iceland and research on migration and local services, Ólafsson (1997) has made a significant empirical contribution. According to his results, migration is a decision relating to the overall estimation of the quality of life provided locally through: employment level, variety of employment, culture, leisure opportunities, access to services and shopping, housing and efficient transportation. Among the services provided by the local government that made a significant impact were sports and recreation and primary and play school. Furthermore, many mid-sized communities were doing better than the capital area in these matters, while the smallest urban communities seemed to do worse in providing some of these important household needs. This study was based on a national survey where the respondents were asked how satisfied they were with 24 factors concerning the quality of life. This data was compared to the local population development to detect possible reasons for interregional migration in Iceland. Benediktsson and Nielsen (2008) came to the same conclusion in an empirical study based on a survey, as did Karlsson and Eythórsson (2009), especially regarding factors connected to family, that is, the welfare of children. Based on the same data sample as Karlsson og Eythórsson, Karlsson and Jóhannesdóttir (2010) concluded that women were more concerned about factors relating to children, family issues and household economies - all of which were highly relevant to matters that include services of local authorities. All the above-mentioned papers were based on survey data - mostly in areas outside the capital area of Iceland. According to Karlsson (2013), women's migration was of more concern than men's migration. Thus, a municipality's ability to address this particular issue must be highly significant.

There are several discrepancies when it comes to the financial return of municipal amalgamation, or even the financial viability of small units. The contribution of this paper is to detect the financial return of municipal amalgamation by implementing a new method to analyse a robust data sample from Iceland. This data sample was also unique since the municipalities were so small in terms of population.

\section{The empirical model}

The current empirical model is based on previous work by Karlsson (2013) and a similar database where the internal migration pattern in Iceland was analysed. This work was selected because it is one of the most extensive analyses for interregional migration in 
Iceland and the largest existing data sample. We wanted to extend the work in order to reach a more comprehensive understanding of the migration patterns in Iceland as these have been challenging lately. The model had to be an interregional migration model since it generates the explanatory variable of the study. According to Karlsson (2013), the Harris-Todaro model was chosen for this study out of the many good models available, such as the gravity model and the core-periphery model, because this particular framework suited the purpose of the study, the conditions in Iceland and the characteristics of the data sample.

Many empirical models have been developed based on the Harris-Todaro framework, and it has been used in several empirical studies among developed countries (Beladi \& Marjit 1996; Butzer, Larson, \& Mundlak 2002; Fidrmuc 2004; Greenwood \& Hunt 1984; Greenwood, Hunt, Rickman, \& Treyz 1991; Mueser \& Graves 1995; Pekkala 2003; Treyz, Rickman, Hunt, \& Greenwood 1993), even though it was constructed to analyse interregional migration in less developed countries. One elegant example is found in Greenwood's (1991) paper. According to Harris and Todaro (1970), interregional migration is dependent on the tension between the wages offered in the regions and unemployment (or expected wages). The contribution of Greenwood et al. (1991) was to establish that

$$
\text { Eq. } 1 \quad\left[\left(N L F_{t-1}+E C M_{t}\right) / N L F_{t-1}\right]=f\{[N P V(E I) / N P V(\overline{E I})],[A / \bar{A}]\}
$$

where net migration is the sum of the natural labour force in the previous period, $N L F_{t-1}$, and economic migration, $E C M_{t}$, divided by the natural labour force in the previous period. Economic migration is defined by Greenwood et al. (1991) and Treyz et al. (1993) as the net economic migration of individuals who base their decisions on economic factors; non-economic migrants in their study included military personnel, U.S. immigrants, and elderly persons (Treyz et al. 1993). The natural labour force is represented by the potential workers (those of a certain age) in the local population, rather than the estimation of local employment. Economic migration is limited to the net migration of people of the same age, and interregional migration is dependent on relative income and amenities. To capture workers' life time earnings, the net present value of income, $N P V(E I)$, is calculated and compared to other regions, $N P V(\overline{E I})$. Local amenities, $A$, are compared to the domestic average amenity value, $\bar{A}$.

Lifetime earnings are the net present value of expected income in each region, where $\tilde{g}$ is the expected growth rate, $\tilde{\rho}$ is the expected discount rate, and $\phi$ is the fixed proportion of income required for migrating:

$$
N P V_{t_{o}}=E I_{t_{o}}\left\{\left[\sum_{t=t_{0}}^{T} \frac{(1+\tilde{g})^{t-t_{0}}}{\left((1+\tilde{\rho})^{t-t_{0}}\right)}\right]-\phi\right\}
$$

Greenwood et al. (1991) assumed it was possible to estimate expected income using relative income (the 'wage bill'), RI, and the natural labour force. Thus, Eq. 1 becomes 


$$
\text { Eq. } 2 \quad\left[\left(N L F_{t-1}+E C M_{t}\right) / N L F_{t-1}\right]=f\{R I,[A / \bar{A}]\}
$$

By taking the natural logarithm of both sides, the empirical model becomes

$$
\ln \left[\left(N L F_{t-1}+E C M_{t}\right) / N L F_{t-1}\right]=\ln \alpha+\beta \ln R I_{t}+e_{t}
$$

where relative expected income is the only explanatory variable, and the individual constant term, $\alpha$, captures the local amenities. Local public service is one of the local amenities. So, if a municipality amalgamation were successful and used to increase local public service it would be detected in the constant term traced by a standard dummy variable. Note that local taxes will be explicit in present empirical model.

Travel distances are not explicitly included in the model, but transportation improvements tend to affect household income, especially when adjacent regions have better access to urban labour markets because of the agglomeration economies (Karlsson 2013).

The model will be a fixed effect model where the variable coefficient returns a "within individual variation" (or the time variation) and the "between individual variation" is captured by the individual constant term,

$$
\text { Eq. } 3 m_{i t}=\alpha_{i}+i_{i t} \beta_{1}+s_{i t} \beta_{3}+s_{i t}^{2} \beta_{4}+u_{i t} \beta_{5}+u_{i t}^{2} \beta_{6}+v_{i t} \beta_{7}+x_{i t}^{\prime} \beta_{8}+d_{i t}^{\prime} \beta_{9}+\varepsilon_{i t} \text {, }
$$

where net interregional migration, $m$, is dependent on relative income, $i$, relative amenities, $a$, the travel distances, $s, u$, and $v$, to the central business districts (CBD), a vector of relevant additional explanatory variables, $x^{\prime}$, a vector of relevant dummy variables, $d^{\prime}$, and the residuals, $\varepsilon$, of every municipality, $i$, in every single period, $t$. Note that $\alpha_{i}$ is the individual constant term and amenities are represented explicitly.

All variables included in the model relate to the work of Tiebout (1956) and his followers, such as Graves (1979), Roback (1982) and Blomquist et al. (1988), except for distance, which is the contribution of Karlsson (2013). Relative local taxes are present due to the work of Tiebout (1956). The supply and price of dwellings, demographic variables (age, gender, population), climate variables (temperature and wind speed) are based on the work of Blomquist et al. (1988). All the many different amenity variables (see Appendix) are in line with Roback's (1982) work. Finally, other explanatory variables relate to standard explanatory variables of disequilibrium models, such as income and other factors that might implicitly affect income as, for example, transferable fishing quotas. The entire list is in the next section (see Table 4). Many dummy variables are present. One of them is the key variable; variables for amalgamated municipalities were added to the prior database for the purpose of the present study. Other variables relate to the establishment of a large aluminium smelter plant in 1998 in eastern Iceland, and a couple of them represent local tragedies, like the two snow avalanches in the Westfjords in 1995.

The fourth largest urban community in Iceland, Akureyri, approximately $400 \mathrm{~km}$ away from the capital, suggested that a polycentric model should be implemented instead of a monocentric model. The variables $s, u$ and $v$ cover the polycentric construc- 
tion of the model, where $S$ is the travel distance to Reykjavik from the municipalities closer to Reykjavik than Akureyri, and $u$ is the distance to Akureyri from municipalities closer to Akureyri than Reykjavik. The variable $v$, however, is the additional distance to Reykjavik from the municipalities closer to Akureyri than Reykjavik. This is in line with Karlsson (2013) and Partridge, Rickman, Ali, and Olfert (2009, 451). Any additional details regarding the model are discussed in Karlsson (2013).

This model (Eq. 3) is suitable for the evaluation of the relationship between migration and municipality mergers, because the model captures all previous explanatory variables regarding migration, and the dummy variables for municipal amalgamations capture the instant change following amalgamations in small island communities, like those found in Iceland, that are geographically isolated from any close borders.

\section{Data}

The model needs an extensive database to cover all the necessary variables. These were gathered from various sources that collect the necessary data on a regular basis.

The data sample covering the period from 1993 through 2006 was delivered as municipalities' annual average numbers except for population and road distances which were static. Data on population are taken as of 1 December every year, and the data on road distance are taken as of 1 January every year. During this period, there were quite a number of amalgamations of municipalities. To retain comparability, the data were transformed into one identical sample of 79 municipalities completely comparable to the situation in the year 2006. This means that all data for the dependent and explanatory variables were either averages or the sum of all joined municipalities prior to the amalgamations. Accordingly, the dummy or the count variables for the amalgamations shift from 0 (prior to amalgamation) to 1 (after the amalgamation) detecting whether the internal migration changes significantly follow the amalgamations while simultaneously observing the development of many other theoretically relevant explanatory variables. All values have been corrected for annual inflation in Iceland. One national price index was implemented since regional price indexes have never been compiled in Iceland. 
Table 1. Varying Number of Municipal Amalgamations

\begin{tabular}{|c|c|c|c|c|c|c|c|c|}
\hline Year / number of amalgamations & 2 & 3 & 4 & 5 & 6 & 7 & 11 & Grand Total \\
\hline 1993 & 1 & & & & & & & 1 \\
\hline 1994 & 6 & 2 & 3 & & 1 & & & 12 \\
\hline 1995 & & 1 & & & & & & 1 \\
\hline 1996 & & & & & 1 & & & 1 \\
\hline 1997 & & 1 & & & & & & 1 \\
\hline 1998 & 3 & 2 & 4 & 1 & & 1 & 1 & 12 \\
\hline 1999 & & & & & & & & 0 \\
\hline 2000 & & & & & & & & 0 \\
\hline 2001 & 2 & 1 & 1 & & 1 & & & 5 \\
\hline 2002 & 3 & 2 & & & & & & 5 \\
\hline 2003 & 1 & & & & & & & 1 \\
\hline 2004 & 1 & 1 & 2 & & & & & 4 \\
\hline 2005 & & & 2 & & & & & 2 \\
\hline 2006 & 5 & 1 & 1 & & & & & 7 \\
\hline Grand Total & 22 & 11 & 13 & 1 & 3 & 1 & 1 & 52 \\
\hline
\end{tabular}

The count variables for municipal amalgamations were constructed with regard to information collected by the Icelandic Association of Local Authorities. The variables take the value one at the year of the first amalgamation, two for the second amalgamation and up to four, since one municipality has had four amalgamations comprising two municipalities which were the offspring of earlier amalgamations. No amalgamations were noted by zeros. The count variables were seven in two groups. One group of five variables for the amalgamation of two to more than four municipalities and two for mergers of similar or different municipalities. Most amalgamations were between two municipalities (Table 1) and there were fewer amalgamations of similar municipalities than different, or 11 out of 52 (Table 2). The data for the one and only amalgamation in 1993 (or 1996 when the shorter data sample was used) were not applicable in our estimation since it was the first year of the entire database.

Amalgamations of two to four municipalities are most common in the relevant period in Iceland. The number of amalgamations of a certain type is counted for all the relevant years in each cell in Table 1. Moreover, amalgamations of "different municipalities" are more common than "similar municipalities" and their number is counted for each year in Table 2, accordingly. The amalgamations were classified as similar if the populations of the municipalities concerned were all only counted either by tens, hundreds or thousands and not if they were counted in both tens and hundreds or hundreds and thousands. 
Grétar Thór Eythórsson

\section{STJÓRNSÝSLA}

Table 2. Amalgamations of Similar and Different Municipalities

\begin{tabular}{lccc}
\hline Year & Similar & Different & Total \\
\hline 1993 & 1 & 0 & 1 \\
1994 & 1 & 11 & 12 \\
1995 & 0 & 1 & 1 \\
1996 & 0 & 1 & 1 \\
1997 & 0 & 1 & 1 \\
1998 & 0 & 12 & 12 \\
1999 & 0 & 0 & 0 \\
2000 & 0 & 0 & 0 \\
2001 & 3 & 2 & 5 \\
2002 & 2 & 3 & 5 \\
2003 & 1 & 0 & 1 \\
2004 & 1 & 3 & 4 \\
2005 & 0 & 2 & 2 \\
2006 & 2 & 5 & 7 \\
\hline Grand Total & 11 & 41 & 52 \\
\hline
\end{tabular}

A different classification was also implemented in the analysis. This was done by counting similar or different municipalities along with their number in one count variable (Table 3)

Table 3. Amalgamations of Similar and Different Municipalities Along with Number of Municipalities

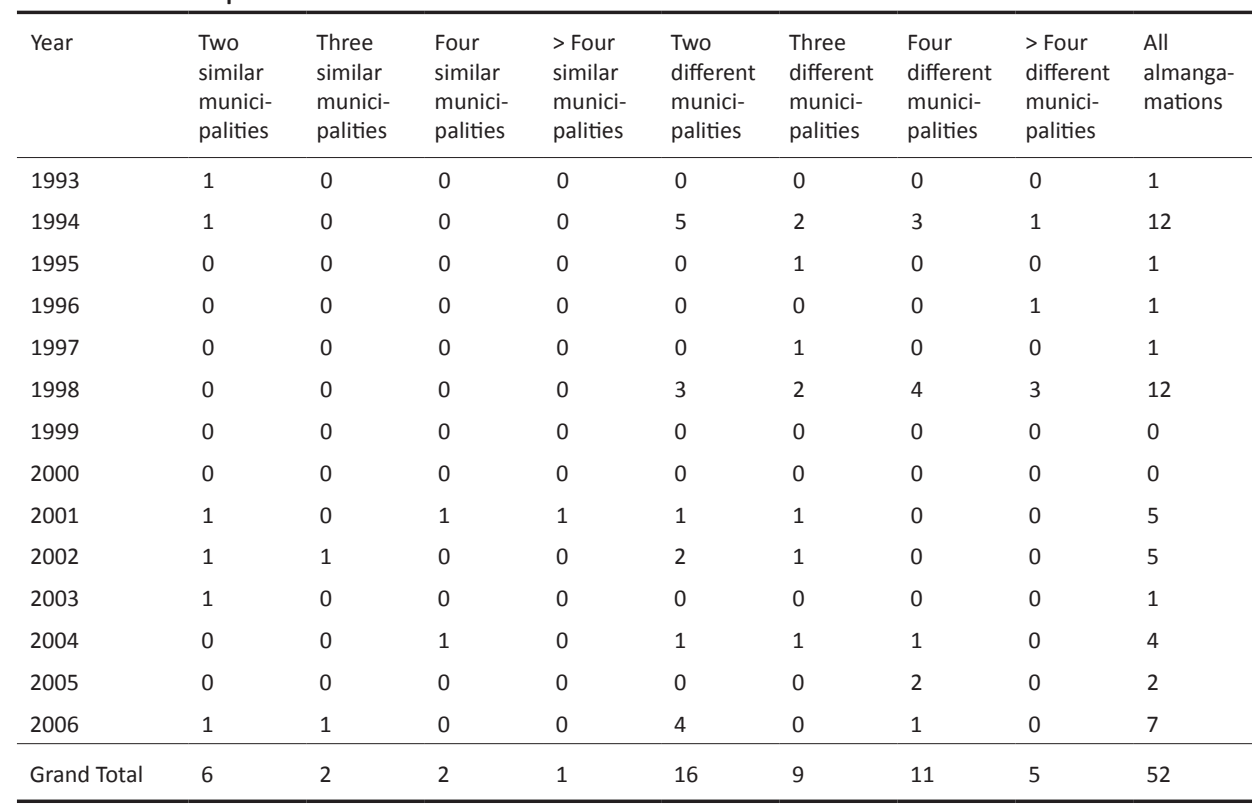




\section{STJÓRNSÝSLA}

Statistics Iceland contributed with data for real labour income, labour market size, gender balance, local population average age and local population. Labour market size was defined as all individuals aged 16-74 years. This is comparable to the definition of Statistics Iceland regarding the age of the most active part of the work force in Iceland. All data, except labour income, came from the public population register. Statistics Iceland collects labour income from the Commissioner of Inland Revenue that originally comes from income tax returns.

Data for migration only related to internal migration and not international migration. The data came from Statistics Iceland and were based on data for registered residency of the population of Iceland. The data for registered residency are published 1 January every year. The data came as an annual net internal migration of every single municipality in Iceland and only applied to people aged 16-74 as suggested in the Harris-Todaro model. It is arguably the most relevant share of the population regarding the labour market, flexibility and those who make moving decisions. Furthermore, the HarrisTodaro model calculated the net migration, miec, as the sum of the local workforce 5 $l_{t-1}$, in the previous period, $m_{l}$, and the net migration in the present period, $m_{l}$, divided by the local workforce in the previous period. This gives us the following formula: miec $=\left(l_{t-1}+m_{l}\right) / l_{t-1}$. Traditionally, the population in the 16-74 age range, has been counted as the workforce in Iceland.

Two types of information were needed for travel time: total road distances and the total length of paved roads (by asphalt). The former was based on the work of Fjölvís and the second on Eymundur Runólfsson, a former employee of the Icelandic Road Administration as mentioned in Karlsson (2012). The data sample was identical to his and thus any additional details of the data management will be found there, where it is shown that travel time changes following a shortening of road distances and newly paved gravel roads.

A large portion of the data was collected by questionnaires to the local authorities to detail local amenities. All municipalities or regional development centres were sent a list of amenities (see Table A1) and asked whether they were present or not in the municipality. Information was also gathered on natural disasters, weather conditions and other relevant facilities as well. Most of this data was represented by dummy variables, where the dummy variable took the value 1 during the given year if the relevant amenity was present somewhere in the municipality and 0 otherwise. The complete list of the amenity dummy variables is presented in the Appendix. Wind speed and temperature were the only continuous variables and their data come from the Icelandic Met Office. Here the classification was, however, by counties.

"Fishing quota" was the fishing quota delivered to the local fisheries each year. Only quotas for demersal and the flat fish species were included. The pelagic species catch was relatively large in quantity and could therefore contribute to heteroscedasticity, if included. Moreover, cod (a demersal species) was the most valuable fish in Icelandic waters and other demersal and flat fish species were accompaniments. The entire industry regarding the demersal fisheries was more labour-intensive than that relating to 
the pelagic fisheries. Therefore, the potential impact of each unit of those species was relatively greater than of the pelagic species.

Table 4. Variable Descriptions and Sample Statistics

\begin{tabular}{|c|c|c|c|}
\hline Variable (acronym) & Description & Mean & $\begin{array}{l}\text { Standard } \\
\text { deviation }\end{array}$ \\
\hline Net migration & $\begin{array}{l}\text { Sum of labourers in the previous period and net inflow of labourers } \\
\text { divided by the number of labourers in the previous period. Number of } \\
\text { labourers is defined as citizens in the age range of } 16-74 \text { years old. }\end{array}$ & 0.9837289 & 0.0330556 \\
\hline $\begin{array}{l}\text { Expected labour } \\
\text { income }\end{array}$ & $\begin{array}{l}\text { Relative expected income (in Icelandic krónur). Local labour income } \\
\text { per capita divided by its national average. }\end{array}$ & 1.00244 & 0.2112292 \\
\hline Number of dwellings & $\begin{array}{l}\text { Relative number of dwellings. New dwellings (number of dwellings } \\
\text { minus the number in the previous period) divided by number of dwell- } \\
\text { ings, an artificial value for housing supply. }\end{array}$ & 0.0109337 & 0.0308228 \\
\hline Local income taxes & $\begin{array}{l}\text { Relative local income taxes. Local income tax rate divided by the } \\
\text { national average. }\end{array}$ & 1 & 0.0320754 \\
\hline $\begin{array}{l}\text { Travel time to Reyk- } \\
\text { javík }\end{array}$ & $\begin{array}{l}\text { Travel time between Reykjavík and municipalities closer to Reykjavík } \\
\text { than to Akureyri, counted in minutes. }\end{array}$ & 72.55162 & 103.0186 \\
\hline $\begin{array}{l}\text { Travel time to } \\
\text { Akureyri }\end{array}$ & $\begin{array}{l}\text { Travel time between Akureyri and municipalities closer to Akureyri } \\
\text { than to Reykjavík, counted in minutes. }\end{array}$ & 43.36302 & 78.16363 \\
\hline $\begin{array}{l}\text { Additional travel } \\
\text { time to Reykjavík }\end{array}$ & $\begin{array}{l}\text { Travel time between Reykjavík and municipalities closer to Akureyri } \\
\text { than Reykjavík, counted in minutes. }\end{array}$ & 79.88288 & 119.6747 \\
\hline Housing price & $\begin{array}{l}\text { Relative housing price (in Icelandic krónur). Local housing price per } \\
\text { square metre divided by the national average. }\end{array}$ & 0.9999989 & 0.4400329 \\
\hline Fishing quotas ITQ & $\begin{array}{l}\text { Relative ITQ. Local transferable fishing quotas (only demersal and flat } \\
\text { fish) divided by the national average. }\end{array}$ & 1 & 1.867678 \\
\hline Gender ratio & $\begin{array}{l}\text { Relative gender ratio. Gender ratio is the number of females divided by } \\
\text { the number of males. }\end{array}$ & 1 & 0.1142768 \\
\hline $\begin{array}{l}\text { Local population } \\
\text { average age }\end{array}$ & Relative average age. Local average age divided by national average. & 1 & 0.0850392 \\
\hline Local population & $\begin{array}{l}\text { Relative population. Local population of municipalities divided by the } \\
\text { national average. }\end{array}$ & 1 & 3.481913 \\
\hline Temperature & $\begin{array}{l}\text { Relative average temperature. Average temperature in the relevant } \\
\text { county divided by the national average. }\end{array}$ & 1 & 0.2105711 \\
\hline Wind speed & $\begin{array}{l}\text { Relative average wind speed. Average wind speed in the relevant } \\
\text { county divided by the national average. }\end{array}$ & 1 & 0.3021071 \\
\hline $\begin{array}{l}\text { All municipalities } \\
\text { amalgamation }\end{array}$ & A count variable for the amalgamation of all municipalities & 0.3179487 & 0.7180413 \\
\hline Similar municipalities & A count variable for the amalgamation of similar municipalities & 0.0141772 & 0.118251 \\
\hline $\begin{array}{l}\text { Different munici- } \\
\text { palities }\end{array}$ & A count variable for the amalgamation of different municipalities & 0.0693671 & 0.2806642 \\
\hline Two municipalities & A count variable for the amalgamation of two municipalities & 0.0258228 & 0.1586465 \\
\hline Three municipalities & A count variable for the amalgamation of three municipalities & 0.0202532 & 0.1479168 \\
\hline Four municipalities & A count variable for the amalgamation of four municipalities & 0.0177215 & 0.1357551 \\
\hline$>$ four municipalities & A count variable for the amalgamation of more than four municipalities & 0.0156962 & 0.1243288 \\
\hline
\end{tabular}

The explanatory variables included in Eq. 3 are drawn from sources that include the Commissioner of Inland Revenue, Statistics Iceland, and the Icelandic Road Administration. Information for the number and prices of dwellings was obtained from the Land Registry of Iceland. Data on road distances were received from Fjölvís Publishing Company and were originally collected by the Icelandic Road Administration. The data on unemployment and total income were received from the Directorate of Labour and the Icelandic Regional Development Institute. The Commissioner of Inland Revenue is the primary source for labour income. The Directorate of Fisheries contributed data on fishing quotas. 


\section{Estimating results}

The data was estimated according to the empirical model in Eq. 3. It is reasonable to suggest that the impact of amalgamations does not affect instantly and therefore the model was estimated for lagged variables of mergers for one, two and three years. A one-year-lagged variable model was an improvement from the standard model while the other two returned a less significant result. Thus, the present results are (Model 1 to Model 4) for the one-year-lagged variable model. Four versions of the model were estimated and the difference between those versions will be discussed later. The results will be presented in three tables. First, the main results will be in Table 5. Second, the results for the time dummies will be found separately in Table A2 in the Appendix. Third, the results for the set of several amenity factors used in the final models will be addressed in Table A3, separately as well.

When it comes to the present research question, the results of Model 1 suggest that amalgamations of four municipalities have a weak negative impact on net migration of people aged between 16 and 74; they fuel out-migration and/or discourage in-migration. The results, however, imply that amalgamations of similar municipalities have a weak positive effect on net migration (both coefficients were close to being significant at the $10 \%$ level). The size of the coefficients for three- and four-municipality mergers fuels the suggestion that the fewer the municipalities in each merger the more positive their impact is on net-migration. The results for five-municipality mergers contradict that statement. However, there was only one amalgamation of five municipalities in the data sample (Table 3). The other results are in line with Karlsson (2013).

Since the results in the initial model were generally weak and not significant, even though some of them came close to significance, several other versions of the model were investigated. First, the estimation of the model was repeated (as Model 2) without any insignificant independent variables from the previous estimation, apart from several technically necessary variables, such as the time dummies and variables for travel time. The result regarding municipalities was disappointing since it did not return any significant improvements concerning variables for municipal amalgamations.

Next, attention was directed towards the number of observations for municipalities. The number of classifications was greatly reducing the possible counts for each variable. Therefore, we next attempted to estimate the model without any classifications of municipal mergers and construct one count variable for them all. The results, however, did not improve sufficiently, since the coefficient became -0.005187 and the t-value -1.14 .

Model 4 was the final attempt to increase the number of municipal amalgamations in the analysis. It was done by discarding one of the significant explanatory variables, the number of dwellings. Since this variable covered the shortest period of time (19962006) in the entire database, excluding it allowed the examination of a data sample for the period from 1993 through 2006. This was tempting since it would increase the number of amalgamations in the analysis, especially since the annual number of municipal amalgamations has never been higher than 12 in Iceland in the years 1994 and 


\section{STJÓRNSÝSLA}

1998. So, by reaching back to the year 1993, we were able to increase the number of amalgamations by 14 (see Tables $1-3$ ). It also potentially improved the migration data with the three additional years for adjustment to possible slow reactions of any potential migrants brought about by the local changes following amalgamations. Surprisingly, however, the results of Model 4 suggested that net-migration became negative following an amalgamation of municipalities, which is not in line with Tiebout's theory. It could, however, have been due to discarded variables. In order to test for this, we repeated the estimation of Model 4 for the period 1996-2006 and compared the result (not shown in a table) of the amalgamation variable to that of Model 3. The comparison showed that the two were almost identical where the coefficient was 0.0052241 and the $t$-value -1.14. This suggested that changes in the amalgamation variable between Model 3 and Model 4 were not due to the omitted variable (number of dwellings). This is, however, in line with Verbeek $(2004,345)$ who argued that the effects of the omitted variable bias can be negligible in panel data, as in the present study. Thus, it was more likely that the significant negative coefficient of the dependent variable for the amalgamation of municipalities was due to better information regarding the matter; the amalgamations of municipalities were increased in number and the period of time was extended, as far as possible, by three years. Therefore, the current analysis suggests that municipal amalgamations have not been successful in Iceland. It is even possible that they have been harmful to the communities involved.

Half of all amalgamations in Iceland during the period were included in the final estimations.

Neither multicollinearity nor autocorrelation were present in the final results. A version of the robust estimator regression model was implemented due to the presence of heteroscedasticity. Observations for Reykjavík were omitted since it is exceptionally large in terms of population compared to other municipalities in Iceland, both because of the risk of a possible outlier effect and the presence of heteroscedasticity. The models were unbalanced and the final versions of the models contained 643, 753, and 1002 observations. 
Table 5. Main Results of the Regression Analysis. Fixed Effect Panel Data Models

\begin{tabular}{|c|c|c|c|c|}
\hline Variable (acronym) & $\begin{array}{c}\text { Model } 1 \\
\text { Coefficient (t-value) }\end{array}$ & $\begin{array}{c}\text { Model } 2 \\
\text { Coefficient (t-value) }\end{array}$ & $\begin{array}{c}\text { Model } 3 \\
\text { Coefficient (t-value) }\end{array}$ & $\begin{array}{c}\text { Model } 4 \\
\text { Coefficient (t-value) }\end{array}$ \\
\hline Expected labour income (lier) & $0.063289(1.86)^{*}$ & $0.044334(2.70)^{* *}$ & $0.206786(1.90)^{*}$ & $0.155330(2.07)^{* *}$ \\
\hline Number of dwellings (hshn) & $0.214195(2.94)^{* *}$ & $0.147684(3.48)^{* * *}$ & $0.155954(3.43)^{* * *}$ & $\# \mathrm{~N} / \mathrm{A}$ \\
\hline Local income taxes (lotr) & $0.133973(1.39)$ & $\# N / A$ & $0.082022(0.99)$ & $0.003493(0.08)$ \\
\hline Travel time to Reykjavík (ttre) & $0.000230(0.43)$ & $0.000439(1.71)^{*}$ & $0.000524(1.23)$ & $0.000412(1.44)$ \\
\hline $\begin{array}{l}\text { Travel time to Reykjavík, } \\
\text { squared (ttre2) }\end{array}$ & $-0.000001(-0.87)$ & $-0.000001(-2.33)^{* *}$ & $-0.000002(-2.36)^{* *}$ & $-0.000001(-1.55)$ \\
\hline Travel time to Akureyri (ttak) & $0.001541(2.21)^{* *}$ & $0.001252(2.41)^{* *}$ & $0.001166(1.61)$ & $0.000725(1.66)^{*}$ \\
\hline $\begin{array}{l}\text { Travel time to Akureyri, } \\
\text { squared (ttak2) }\end{array}$ & $-0.000009(-2.92)^{* *}$ & $-0.000006(-2.46)^{* *}$ & $-0.000006(-1.78)^{*}$ & $-0.000002(-1.45)$ \\
\hline $\begin{array}{l}\text { Additional travel time to } \\
\text { Reykjavík (ttrm) }\end{array}$ & $-0.000521(-1.59)$ & $-0.000504(-1.01)$ & $-0.000573(-1.07)$ & $-0.000016(-0.04)$ \\
\hline $\begin{array}{l}\text { Additional travel time to } \\
\text { Reykjavík, squared }\end{array}$ & $0.000002(3.08)^{* *}$ & $0.000001(1.50)$ & $0.000002(1.73)^{*}$ & $0.000001(0.75)$ \\
\hline $\begin{array}{l}\text { Closer to Reykjavík than } \\
\text { Akureyri (dmr1) }\end{array}$ & $0.019673(2.62)^{* *}$ & $0.022165(0.85)$ & $0.013674(0.52)$ & $0.015529(0.62)$ \\
\hline Housing price (hprr) & $-0.010146(-1.95)^{*}$ & $\# N / A$ & $-0.007384(-1.56)$ & $-0.008254(-1.97)^{* *}$ \\
\hline Fishing quotas, ITQ (rrqr) & $0.001596(0.89)$ & $\# N / A$ & $0.004161(1.24)$ & $0.002250(1.03)$ \\
\hline $\begin{array}{l}\text { Local population average age } \\
\text { (pagr) }\end{array}$ & $-0.253110(-2.67)^{* *}$ & $-0.223068(-3.06)^{* *}$ & $-0.209709(-2.28)^{* *}$ & $-0.205780(-3.17)^{* *}$ \\
\hline Local population (popr) & $-0.018849(-1.13)$ & $\# N / A$ & $-0.024459(-1.65)^{*}$ & $-0.007196(-0.79)$ \\
\hline Hvalfjörður Tunnel (tun3) & $0.009838(0.61)$ & $\# N / A$ & $0.008046(0.52)$ & $0.010164(0.90)$ \\
\hline $\begin{array}{l}\text { Large-scale energy-intensive } \\
\text { production plant (poin) }\end{array}$ & $-0.037578(-2.73)^{* *}$ & $\# \mathrm{~N} / \mathrm{A}$ & $-0.018436(-1.20)$ & $-0.010888(-0.92)$ \\
\hline $\begin{array}{l}\text { Elimination of the scallop } \\
\text { stock (shel) }\end{array}$ & $-0.002808(-0.17)$ & $\# \mathrm{~N} / \mathrm{A}$ & $0.002513(0.13)$ & $0.004472(0.26)$ \\
\hline Temperature (temr) & $0.038404(3.01)^{* *}$ & $0.029899(1.97)^{* *}$ & $0.026452(1.62)$ & $0.019147(1.38)$ \\
\hline Wind speed (winr) & $0.003390(0.26)$ & $\# N / A$ & $0.012195(0.89)$ & $0.008911(0.87)$ \\
\hline Gender ratio (Iger) & $-0.019140(-0.63)$ & $\# \mathrm{~N} / \mathrm{A}$ & $\# N / A$ & $\# \mathrm{~N} / \mathrm{A}$ \\
\hline $\begin{array}{l}\text { Merger of similar municipali- } \\
\text { ties (amall1_sinht) }\end{array}$ & $0.026468(1.63)$ & $0.025450(1.37)$ & $\# \mathrm{~N} / \mathrm{A}$ & $\# \mathrm{~N} / \mathrm{A}$ \\
\hline $\begin{array}{l}\text { Merger of different municipali- } \\
\text { ties (amalo1_sinht) }\end{array}$ & $0.012814(1.02)$ & $0.016683(1.05)$ & $\# \mathrm{~N} / \mathrm{A}$ & $\# \mathrm{~N} / \mathrm{A}$ \\
\hline $\begin{array}{l}\text { Merger of two municipalities } \\
\text { (amal2_sinht) }\end{array}$ & $-0.008068(-0.59)$ & $-0.015498(-0.92)$ & $\# \mathrm{~N} / \mathrm{A}$ & $\# \mathrm{~N} / \mathrm{A}$ \\
\hline $\begin{array}{l}\text { Merger of three municipalities } \\
\text { (amal3_sinht) }\end{array}$ & $-0.024984(-1.30)$ & $-0.025456(-1.35)$ & $\# \mathrm{~N} / \mathrm{A}$ & $\# \mathrm{~N} / \mathrm{A}$ \\
\hline $\begin{array}{l}\text { Merger of four municipalities } \\
\text { (amal4_sinht) }\end{array}$ & $-0.023303(-1.62)$ & $-0.023672(-1.37)$ & $\# \mathrm{~N} / \mathrm{A}$ & $\# \mathrm{~N} / \mathrm{A}$ \\
\hline $\begin{array}{l}\text { Merger of more than four } \\
\text { municipalities (amal6_sinht) }\end{array}$ & $-0.016937(-1.18)$ & $-0.019873(-1.04)$ & $\# \mathrm{~N} / \mathrm{A}$ & $\# \mathrm{~N} / \mathrm{A}$ \\
\hline All mergers (amal) & $\# N / A$ & $\# N / A$ & $-0.005187(-1.14)$ & $-0.006729(-2.36)^{* *}$ \\
\hline Lagged variable & $-0.099746(-2.20)^{* *}$ & $\# N / A$ & $\# \mathrm{~N} / \mathrm{A}$ & $\# \mathrm{~N} / \mathrm{A}$ \\
\hline Constant term (_cons) & $1.041769(6.62)^{* * *}$ & $\# \mathrm{~N} / \mathrm{A}$ & $\# \mathrm{~N} / \mathrm{A}$ & $\# \mathrm{~N} / \mathrm{A}$ \\
\hline
\end{tabular}


Table 5. ext.

\begin{tabular}{|c|c|c|c|c|}
\hline Variable (acronym) & $\begin{array}{c}\text { Model } 1 \\
\text { Coefficient (t-value) }\end{array}$ & $\begin{array}{c}\text { Model } 2 \\
\text { Coefficient (t-value) }\end{array}$ & $\begin{array}{c}\text { Model } 3 \\
\text { Coefficient (t-value) }\end{array}$ & $\begin{array}{c}\text { Model } 4 \\
\text { Coefficient (t-value) }\end{array}$ \\
\hline Number of observations, $n$ & 643 & 753 & 753 & 1002 \\
\hline R2 within & 0.1927 & & & \\
\hline $\mathrm{R} 2$ between & 0.0218 & & & \\
\hline R2 overall & 0.0085 & & & \\
\hline R2 centered & & 0.1319 & 0.0424 & 0.052 \\
\hline R2 uncentered & & 0.1319 & 0.0424 & 0.052 \\
\hline Serial correlation, t-test & 0 & -1.63 & -0.34 & 1.41 \\
\hline Multicollinearity & No & No & No & No \\
\hline Heteroskedastisity & Robust & No & No & No \\
\hline Panel data sample & Unbalanced & Unbalanced & Unbalanced & Unbalanced \\
\hline Sargan test ( $p$-value) & & 0.6679 & 0.3909 & 0.8585 \\
\hline
\end{tabular}

Dependent variable net migration (miec) . ${ }^{*}$ significant at the $10 \%$ level; ${ }^{* *}$ significant at the $5 \%$ level; ${ }^{* * *}$ significant at the $1 \%$ level. No endogeneiety was present in model 1 . It was present in model $2-4$ and successfully solved according to Sargan test where $p$-value needed to be larger than 0.1 .

No endogeneity was present in the results of Model 1. It was present in other three and successfully resolved as suggested by the Sargan test p-value (Table 5). Endogeneity was tested in all models against labour income, housing supply, population average age, gender balance, local population and housing prices. Total household income, proportion of senior citizens and housing prices in terms of square metres were instruments for labour income, housing supply, housing prices and gender balance. Share of elderly and housing prices per square metre were instruments for average age. Housing prices per square metre and the distance from Reykjavík were the instruments for local population.

The arguments for the chosen instruments are as follows. Total income should correlate with labour income, where a large share of the total income is labour income. It does not correlate with net migration and thus, the residuals, since all other income was independent of location. This was also true for the proportion of elderly citizens, since older people have a negligible labour income but were, however, less likely to migrate.

Total income should correlate with housing supply since total income can stimulate the housing market and the elderly, since they tend to shift to more suitable apartments when aging. Total income and the share of elderly should correlate with housing prices for the same reasons as apply to the housing supply.

Total income should correlate with gender balance because, unfortunately, women still have lower incomes than men. Moreover, women tend to live longer than men, so the share of elderly should correlate with gender balance.

Housing prices per square metre should correlate with the average age on the same grounds as house prices argued earlier, and the proportion of elderly people should correlate with average age for obvious reasons. 


\section{Discussion}

Low, none, or possibly negative net benefits of amalgamations were to some extent surprising, since theoretical arguments strongly suggest that there should be a positive return on municipal amalgamation. But the literature of empirical studies offered mixed results - some proved to be successful and others not. The explanation may lie in the types of amalgamations or their circumstances, as we conclude in this article - even though the signals were not strong. This might indeed suggest an idea for a next step in the research on municipal amalgamations. That is, one should make a thorough analysis of all previous research in order to detect the pattern of successful amalgamations and those that failed and identify possible causes. As an example, a recent German paper (Blesse \& Baskaran 2013) suggested that voluntary amalgamations were more likely to fail than those that were compulsory. Almost all amalgamations in Iceland have been voluntary.

Let us reassess the views of Oates (1999) prior to any additional attempts at explanations. In his paper, Oates emphasized the necessity of the existence (or "supply") of a tailored provision of local public services in order to be able to meet the vast variety of consumers' public service preferences. Or, as he (1999, 1121-1122) put it:

Decentralized levels of government have their raison d'etre in the provision of goods and services whose consumption is limited to their own jurisdictions. By tailoring outputs of such goods and services to the particular preferences and circumstances of their constituencies, decentralized provision increases economic welfare above that which results from the more uniform levels of such services that are likely under national provision.

Tailored provision includes a heterogeneous sample of municipalities since local communities have different combinations of inhabitants. It might include different preferences with regard to the quality of the service, its quantity, or variety. It might also concern the level of public to private interference and the level of local taxation. So, in that sense, it is "healthy" for the municipalities to compete in various ways, like companies in a market of monopolistic competition.

With a view to the above, a low level of municipal variety in Iceland could be another explanation for poor impact on migration following municipal mergers. Even though Icelandic municipalities seem to be quite different with respect to local population and industrial structure, there is a strict framework of laws and regulations regarding the service provision of municipalities in Iceland. This framework, together with a tight budget, does not provide the municipalities with sufficient flexibility (Ladner, Keuffer, \& Baldersheim 2015) to offer the extent of additional services that might have given them unique characteristics as communities and thus would have helped attract new migrants/customers, as companies would do in a market of monopolistic competition.

Moreover, the smallest and/or the financially weakest municipalities receive annual 
financial contributions from the state and the stronger municipalities - The Local Authorities' Equalization Fund. This along with a strong tradition of inter-municipal collaboration, described earlier, makes it possible for the smaller and weaker municipalities to provide services within the framework laid down by laws and regulations.

Furthermore, if the migration "market" is in equilibrium prior to the amalgamation, thus making the services of the new municipality not that different from any other previous municipality of potential in-migrants, one can hardly expect any notable change in the level of migration flow. This might be due to strict legal obligations of municipalities and a tight budget, as mentioned earlier.

It is also possible that a wide range of inter-municipal cooperation was a significant factor in ensuring that inhabitants had all the necessary services demanded - especially if the expectations and demands (due to the inhabitants' preferences) were pretty low in the smaller municipalities.

Another explanation for the limited success of amalgamations could be poor management of municipalities. Municipal managers and local politicians have different degrees of skill in running their municipalities. Some are able to realise almost all of the possible gain that an amalgamation can generate and others are not. Thus, varying management skills and/or capacity for professional administration might have to be taken into an account when conducting a thorough analysis of the potential benefits of amalgamations.

The varying distance of municipalities from large service centres may also be responsible for the weak results. This was partly accounted for in the analysis by including the distance between all municipalities and the two largest service centres in Iceland (Reykjavík and Akureyri), both of which turned out to be significant. But there were smaller service centres (of 2,500-5,000 inhabitants) that could also matter with regard to the most remote municipalities and might need to be included in the data sample.

Among other reasons, migration thresholds might be higher than the expected return on any tempting migration move. It is known that labour/individuals/families can be immobile due to personal investments such as housing or a personal social network - the latter of which was mentioned by Baldwin $(2001,32)$ and called the "old folks effect". Therefore, it is possible that the net impact of amalgamations, low returns, heterogeneous consumer preferences, poor municipal financial outcomes, tight budgets, inter-municipal collaborations, different management skills, and the function of the Equalisation Fund cannot overcome the threshold of immobility of the citizens. If the migration market was closer to the principles of perfect competition, mobility between municipalities might be observable under the circumstances.

\section{Conclusion}

The results are mixed. They suggest that amalgamations of municipalities with different population sizes had a negative impact on net-migration of people between 16-74 years old - in other words, they fuelled out-migration and/or discouraged in-migration. The results, however, implied that amalgamations of two and five municipalities can 
have a positive effect on net-migration. The size of the coefficients for three- and fourmunicipality amalgamations fuels the suggestion that the fewer the municipalities in each merger context, the more positive is their impact on net-migration. The results for mergers of five municipalities contradicted this statement. It must be kept in mind, however, that there was only one amalgamation of five municipalities in the data sample.

Surprisingly, an extended version of the model returned a negative relationship between municipal amalgamations and net-migration.

These results must be considered as robust, since they were carried out through a substantially sized dataset for all 79 municipalities in Iceland for the period 1993 (or 1996) through 2006 and were estimated by a fixed-effect regression model. Moreover, the results were not violated by a threat of heteroscedasticity, serial correlation, multicollinearity nor endogeneity.

\section{Notes}

1 Hagtíðindi. Statistical Series. Fjármál hins opinbera. Public finance. 15. Mars 2018. file:///C:/Users/gretar/Downloads/download\%20(1).pdf

2 Local Governments in Iceland. Facts and Figures. Assosiation of Local Authorities in Iceland. September 2018. https://www.samband.is/media/tolfraedilegar-upplysingar/Enskur_Baeklingur_ sept_2018.pdf

3 See in Eythórsson et al. (2014)

4 Eythórsson and Arnarson 2012 \& Eythórsson, Sveinsdóttir \& Jóhannesdóttir 2006. Both surveys were conducted among all elected local politicians in Iceland.

5 What Greenwood (1991) calls natural civilian labour force.

\section{References}

Baldersheim, H., and Rose, L. (2010). “Territorial choice: Rescaling governance in European states”, in H. Baldersheim and L. Rose (eds.), Territorial Choice. The Politics of Boundaries and Borders (pp.1-21). London: Palgrave Macmillan.

Baldwin, R.E. (2001). "Core-periphery model with forward-looking expectations", Regional Science and Urban Economics 31(1), 21-49.

Benediktsson, K., and Nielsen, H. (2008). Búseta og pjónusta [Residence and services]. Reykjavík: Háskóli Íslands, raunvísindadeild.

Blesse, S., and Baskaran, T. (2013). "Do municipal mergers result in scale economies? Evidence from a German federal state", Discussion Papers, Center for European Governance and Economic Development Research 176, 1-46.

Blom-Hansen, J. (2010). "Municipal amalgamations and common pool problems: The Danish local government reform in 2007”, Scandinavian Political Studies 33(1), 51-73. doi:10.1111/j.14679477.2009.00239.x

Blom-Hansen, J., Houlberg, K., and Serritzlew, S. (2011). "Scale effects in local government? evidence from local government amalgamations in Denmark", Unpublished paper presented at the XX NORKOM Conference, 24-26 November 2011. Gothenburg, Sweden.

Blomquist, G.C., Berger, M.C., and Hoehn, J.P. (1988). "New estimates of quality of life in urban areas", The American Economic Review 78(1), 89-107.

Burridge, M. (2008). "Scale and efficiency in the provision of local government services", International Journal of Business Performance Management 10(1), 9.

Byrnes, J., and Dollery, B. (2002). "Do economies of scale exist in Australian local government? A review of the research evidence", Urban Policy and Research 20(4), 391-414. 
Constitution of the Republic of Iceland (1999). Retrieved from http://www.government.is/constitution/

Dollery, B., Byrnes, J., and Crase, L. (2007). "Is bigger better? Local government amalgamation and the South Australian rising to the challenge inquiry", Economic Analysis and Policy 37(1), 14.

Dollery, B., Crase, L. and Johnson, A. (2006). Australian Local Government Economics. Sidney, Australia: UNSW Press.

Duncombe, W., Miner, J., and Ruggiero, J. (1995). "Potential cost savings from school district consolidation: A case study of New York", Economics of Education Review 14(3), 265-284.

Duncombe, W., and Yinger, J. (2007). "Does school district consolidation cut costs?”, Education Finance and Policy 2(4), 341-375.

Dur, R., and Staal, K. (2008). "Local public good provision, municipal consolidation, and national transfers", Regional Science and Urban Economics 38(2), 160-173.

Eythórsson, G.T. (2009). "Municipal amalgamations in Iceland. Past, present and future", in G. Baldacchino, R. Greenwood, and L. Felt (eds.), Remote control. Governance Lessons for and from Small, Insular, and Remote Regions. St. John's: Iser Books.

Eythórsson, G.T. (2017). "Bigger and stronger together. how Icelandic municipalities solve their lack of capacity and scale economy", in: F. Teles and P. Swianiewicz (eds.), Intermunicipal Cooperation in Europe. Palgrave. Forthcoming.

Eythórsson, G.T., Gløersen, E., and Karlsson, V. (2014). West Nordic municipal structure: Challenges for local democracy, efficient service provision and adaptive capacity. Report from a project supported by the Arctic Co-operation Programme 2012-2014. Akureyri. RHA.

Eythórsson, G.T., and Arnarsson, S. (2012). Íslensk sveitarstiórnarmál i brennidepli [Icelandic municipal affairs in the spotlight]. Akureyri: University of Akureyri.

Eypórsson, G.T., and Jóhannesson, H. (2002). Sameining sveitarfélaga: Ábrif og afleiðingar. Rannsókn á sjö sveitarfélögum [Municipal amalgamation: Impact and consequences. Research into seven municipalities]. Akureyri: Rannsóknarstofnun Háskólans á Akureyri.

Eythórsson, G.T., Sveinsdóttir, H., and Jóhannesdóttir, K. (2006). Íslenska sveitarstjórnarstigið - viðhorf stjórnmálamanna. Könnun medal sveitarstjórnarmanna og Alpingismanna [The Icelandic Municipal System Attitudes of Politicians]. Borgarbyggð: University of Bifröst Research Centre.

Fox, W.F., and Gurley, T. (2006). "Will consolidation improve sub-national governments?", World Bank Policy Research Working Paper 3913, 1-45.

Graves, P.E. (1979). "A life-cycle empirical analysis of migration and climate, by race", Journal of Urban Economics 6(2), 135-147.

Hicks, J.R. (1932). The theory of wages. New York: Mcmillan.

Hlynsdóttir, E.M. (2015). The Icelandic Mayor. A Comparative Analysis of Political and Administrative Leadership Roles at the Icelandic Local Government Level. Reykjavík: University of Iceland.

Houlberg, K. (2011). "Administrative stordriftsfordele ved kommunalreformen i Danmark - sandede eller tilsandede", Scandinavian Journal of Public Administration 15(1), 20.

Hunt, G.L. (1993). "Equilibrium and disequilibrium in migration modelling”, Regional Studies 27(4), 341349.

Jordahl, H., and Liang, C.-Y. (2010). "Merged municipalities, higher debt: on free-riding and the common pool problem in politics", Public Choice 143, 16.

Jóhannesson, A., Jóhannesson, H., and Eythórsson, G.T. (2016). Samstarfsverkefni Sveitarfélaga [Inter-municipal cooperation in Iceland]. Akureyri: University of Akureyri Research Centre.

Karlsson, V. (2012). Transportation improvement and interregional migration (Ph.D. dissertation). University of Iceland, Reykjavik.

Karlsson, V. (2013). Interregional Migration and Transportation Improvements in Iceland. International Regional Science Review 38(3), 292-315.

Karlsson, V. (2015). “Amalgamation of Icelandic municipalities, average cost, and economic crisis: Panel data analysis", International Journal of Regional Development 2(1), 17-38. 


\section{STJÓRNSÝSLA}

Karlsson, V., and G.P. Eypórsson (2009). “Búsetuskilyrði á Íslandi: hverju sækist fólk eftir?” [Living conditions in Iceland: What are people looking for?], in H.S. Guðmundsson and S.B. Ómarsdóttir, Rannsóknir i félagsvísindum X (p. 365-379). Reykjavik: Félagsvísindastofnun Háskóla Íslands.

Karlsson, V., and Jóhannesdóttir. K. (2010). "Búferlaflutningar kvenna" [Women's residential migration], in I. Hannibalsson, Rannsóknir ífélagsvísindum XI (pp. 235-242). Reykjavík: Félagsvísindastofnun Háskóla Íslands.

Karlsson, V., and Jónsson, E.Á. (2011-2012). "Meðalkostnaður íslenskra sveitarfélaga, fjöldi íbúa og sameining Sveitarfélaga" [Average operational costs of Icelandic municipalities; number of inhabitants and municipal amalgamations], Bifrost Journal of Social Science 5-6, 73-85.

Karlsson, V., and Jóhannesson, T. (2014). Sameiningar sveitarfélaga á Vesturlandi. Möguleikar nokkurra valkosta og bugsanleg ábrif peirra árið 2014 [Municipal amalgamations in West Iceland. Opportunities associated with certain options and their potential impact in 2014]. Borgarnes: SSV. Retrieved from http://www.ssv.is/Files/Skra_0069071.pdf

Ladner, A., Keuffer, N., and Baldersheim, H. (2015). Local Autonomy Index for European countries (19902014). Release 1.0. Retrieved from: https://ec.europa.eu/regional_policy/sources/docgener/studies/pdf/self_rule_index_en.pdf

McCann, P. (2001). Urban and Regional Economics. Oxford, England: Oxford University Press.

Lüchinger, S., and Stutzer, A. (2002). "Skalenerträge in der öffentlichen Kernverwaltung: eine empirische Analyse anhand von Gemeindefusionen", Swiss Political Science Review 8, 27-50.

Moisio, A. (2013). "The impact of municipal mergers on local public expenditures in Finland", Public Finance \& Management 13(3), 148-166.

Oates, W.E. (1999). "An essay on fiscal federalism”, Journal of Economic Literature, 37(3), 1120-1149.

Ólafsson, S. (1997). Búseta á Íslandi: Rannsókn á orsö̈kum búferlaflutninga [Residence in Iceland: Research into patterns of migration]. Reykjavík: Byggðastofnun.

Partridge, M.D., Rickman, D.S., Ali, K., and Olfert, M.R. (2009). "Do new economic geography agglomeration shadows underlie current population dynamics across the urban hierarchy?", Papers in Regional Science 88(2), 445-466.

Reingewertz, Y. (2012). "Do municipal amalgamations work? Evidence from municipalities in Israel", Journal of Urban Economics 72(2-3), 240-251. doi:http://dx.doi.org/10.1016/j.jue.2012.06.001

Roback, J. (1982). "Wages, rents, and the quality of life", The Journal of Political Economy 90(6), 1257-1278.

Rosen, H.S., and Gayer, T. (2008). Public Finance ( $8^{\text {th }}$ ed.). New York: McGraw-Hill/Irwin.

Steiner, R., Kaiser, C., and Eythórsson, G.T. (2016). "A Comparative analysis of amalgamation reforms in selected European countries", in S. Kuhlmann and G. Bouckaert (eds.), Local Public Sector Reforms in Times of Crisis. National trajectories and international comparisons. London: Palgrave MacMillan.

Tiebout, C.M. (1956). "A pure theory of local expenditures", The Journal of Political Economy 64(5), 416424.

Tavares, A.F. (2018). "Municipal amalgamations and their effects: A literature review", Miscellanea Geographica 22(1), 5. doi:https://doi.org/10.2478/mgrsd-2018-0005

Tyrefors Hinnerich, B. (2009). "Do merging local governments free ride on their counterparts when facing boundary reform?", Journal of Public Economics 93(5-6), 721-728.

Valsson, T. (2014). Sveitarstjórnarréttur [Municipal Law]. Reykjavík: Codex.

Verbeek, M. (2004). A Guide to Modern Econometrics (2nd ed.). West Sussex: John Wiley \& Sons, Ltd. 


\section{Appendix}

This chapter provides the entire list of all dummy variables constructed to capture any potential difference in local amenities (Table A1).

Table A1. Additional Dummy Variables Descriptions and Sample Statistics

\begin{tabular}{|c|c|c|}
\hline Variable (acronym) & Mean & Standard deviation \\
\hline Amateur choir (cham) & 0.8442 & 0.3627 \\
\hline Amateur theatre (tham) & 0.5389 & 0.4986 \\
\hline Central pool (pool) & 0.7585 & 0.4281 \\
\hline Central pool and hot tub (poho)* & 0.6714 & 0.4698 \\
\hline Cinema (cine)* & 0.2332 & 0.4230 \\
\hline Distance learning (dile) & 0.1144 & 0.3184 \\
\hline Doctor (doct) & 0.5409 & 0.4984 \\
\hline Elderly home (elho)* & 0.4981 & 0.5001 \\
\hline Elimination of the scallop stock (shel)* & 0.0019 & 0.0441 \\
\hline Ferry (ferr) & 0.0253 & 0.1571 \\
\hline Geothermal energy (geot)* & 0.5798 & 0.4937 \\
\hline Golf course & 0.4961 & 0.5001 \\
\hline Grocery (groc) & 0.7337 & 0.4421 \\
\hline Hvalfjörður tunnel (tun3)* & 0.0175 & 0.1313 \\
\hline Harbour (harb) & 0.6105 & 0.4878 \\
\hline Hospital (hosp) & 0.2205 & 0.4147 \\
\hline Large scale energy intensive production plant (poin)* & 0.0316 & 0.2010 \\
\hline Local festival (lofe) & 0.3783 & 0.4851 \\
\hline Local public transport (buss)* & 0.1728 & 0.3782 \\
\hline Low price groceries (grlo)* & 0.0983 & 0.2979 \\
\hline Motocross arena (moto) & 0.0857 & 0.2800 \\
\hline Music school (cons) & 0.7595 & 0.4275 \\
\hline Natural disasters i.e. earthquakes, snow avalances and eruptions (aval)* & 0.0326 & 0.1777 \\
\hline New entrants in poin (glal) & 0.0190 & 0.1365 \\
\hline Playschool (plsc) & 0.7605 & 0.4269 \\
\hline Police (poli) & 0.4596 & 0.4985 \\
\hline Primary school (prsc) & 0.9211 & 0.2696 \\
\hline Rescue squad (resc) & 0.8179 & 0.3860 \\
\hline Salmon river (salm) & 0.5399 & 0.4985 \\
\hline Skiing arena (skii)* & 0.1879 & 0.3907 \\
\hline Snow avalanche (snow)* & 0.0107 & 0.1030 \\
\hline Sportsclub (spor) & 0.9537 & 0.2101 \\
\hline Theatre (thea) & 0.1923 & 0.3942 \\
\hline Universities, tertiary school & 0.0312 & 0.1738 \\
\hline Upper secondary schools (ussc)* & 0.2439 & 0.4295 \\
\hline
\end{tabular}


Multicollinearity and lack of internal (within) variation prevented many of these from being used in the final estimation. Included variables are marked by asterisks. None of those dummies had any significant impact on the distribution of dependent variables as in Karlsson (2013) apart from a large-scale, energy-intensive production plant, as noted in the table for estimating results.

Table A2. Results for the Time Dummies of the Models in Table 4. A Fixed Effect Panel Panel Data Model

\begin{tabular}{|c|c|c|c|c|}
\hline Variable (acronym) & $\begin{array}{c}\text { Model } 1 \\
\text { Coefficient (t-value) }\end{array}$ & $\begin{array}{c}\text { Model } 2 \\
\text { Coefficient (t-value) }\end{array}$ & $\begin{array}{c}\text { Model } 3 \\
\text { Coefficient (t-value) }\end{array}$ & $\begin{array}{c}\text { Model } 4 \\
\text { Coefficient ( } t \text {-value) }\end{array}$ \\
\hline Time dummy 1996 (tdum16) & $-0.012256(-1.91)^{*}$ & $-0.002523(-0.60)$ & $-0.001614(-0.35)$ & $-0.007455(-2.21)^{* *}$ \\
\hline Time dummy 1997 (tdum17) & $-0.006851(-1.05)$ & $0.003577(0.85)$ & $0.003914(0.86)$ & $-0.003337(-0.98)$ \\
\hline Time dummy 1998 (tdum18) & $-0.007022(-1.25)$ & $0.001058(0.23)$ & $0.000294(0.06)$ & $-0.004453(-1.17)$ \\
\hline Time dummy 1999 (tdum19) & $0.000178(0.03)$ & $0.007220(1.55)$ & $0.007609(1.51)$ & $0.003027(0.79)$ \\
\hline Time dummy 2000 (tdum20) & $0.002195(0.49)$ & $0.009831(2.07)^{* *}$ & $0.011338(2.14)^{* *}$ & $0.006657(1.67)^{*}$ \\
\hline Time dummy 2001 (tdum21) & $0.004853(1.05)$ & $0.013781(2.92)^{* *}$ & $0.014962(2.90)^{* *}$ & $0.011822(3.03)^{* *}$ \\
\hline Time dummy 2002 (tdum22) & $0.003681(0.72)$ & $0.011797(2.47)^{* *}$ & $0.015258(2.82)^{* *}$ & $0.011676(2.83)^{* *}$ \\
\hline Time dummy 2003 (tdum23) & $0.003025(0.74)$ & $0.010945(2.26)^{* *}$ & $0.015333(2.69)^{* *}$ & $0.012607(2.94)^{* *}$ \\
\hline Time dummy 2004 (tdum24) & $0.004012(0.82)$ & $0.011007(2.24)^{* *}$ & $0.015725(2.77)^{* *}$ & $0.013611(3.17)^{* *}$ \\
\hline Time dummy 2005 (tdum25) & $-0.000363(-0.08)$ & $0.007256(1.45)$ & $0.012544(2.10)^{* *}$ & $0.011399(2.51)^{* *}$ \\
\hline Time dummy 2006 (tdum26) & $0.000000(0.00)^{* * *}$ & $0.007698(1.51)$ & $0.012642(2.11)^{* *}$ & $0.011528(2.57)^{* *}$ \\
\hline
\end{tabular}

Table A3. Results for the Amenity Factors of the Models in Table 4. A Fixed Effect Panel Data Model

\begin{tabular}{|c|c|c|c|c|}
\hline Variable (acronym) & $\begin{array}{c}\text { Model } 1 \\
\text { Coefficient (t-value) }\end{array}$ & $\begin{array}{c}\text { Model } 2 \\
\text { Coefficient (t-value) }\end{array}$ & $\begin{array}{c}\text { Model } 3 \\
\text { Coefficient (t-value) }\end{array}$ & $\begin{array}{c}\text { Model } 4 \\
\text { Coefficient (t-value) }\end{array}$ \\
\hline Earthquakes, eruptions (avalanches) & $0.004562(1.37)$ & $\# N / A$ & $0.005336(0.81)$ & $0.008107(1.80)^{*}$ \\
\hline Snow avalanche & $0.000000(0.00)^{* * *}$ & $\# N / A$ & $0.007526(0.27)$ & $0.016424(1.18)$ \\
\hline Upper secondary schools (ussc) & $-0.001290(-0.11)$ & $\# N / A$ & $-0.004060(-0.48)$ & $0.004495(0.71)$ \\
\hline Homes for the elderly & $-0.007181(-1.14)$ & $\# N / A$ & $-0.002492(-0.26)$ & $-0.006993(-1.01)$ \\
\hline Geothermal energy (geot) & $-0.021684(-1.86)^{*}$ & $\# \mathrm{~N} / \mathrm{A}$ & $-0.023565(-2.10)^{* *}$ & $-0.013986(-1.88)^{*}$ \\
\hline Cinema (cine) & $0.005516(0.64)$ & $\# N / A$ & $0.004526(0.61)$ & $0.001802(0.31)$ \\
\hline Central pool and hot tub (poho) & $0.000237(0.03)$ & $\# N / A$ & $0.002641(0.35)$ & $0.001417(0.26)$ \\
\hline Skiing arena (skii) & $0.002037(0.13)$ & $\# N / A$ & $0.012592(0.93)$ & $0.000241(0.03)$ \\
\hline Local public transportation (buss) & $-0.001444(-0.18)$ & $\# N / A$ & $0.010088(0.94)$ & $0.012886(1.48)$ \\
\hline Low-priced groceries (grlo) & $-0.002643(-0.55)$ & $\# N / A$ & $0.000505(0.08)$ & $0.001458(0.31)$ \\
\hline
\end{tabular}

